
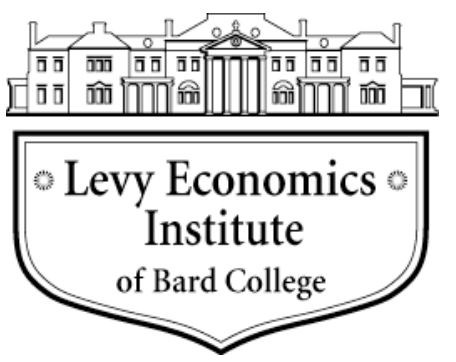

Working Paper No. 720

\title{
What Are the Driving Factors behind the Rise of Spreads and CDSs of Euro-area Sovereign Bonds? A FAVAR Model for Greece and Ireland
}

by

\author{
Nicholas Apergis* \\ Emmanuel Mamatzakis \\ University of Piraeus
}

May 2012

* Address: University of Piraeus, 80 Karaoli \& Dimitriou, 18534 Piraeus, Greece. E-mail: napergis@unipic.gr; tzakis@unipi.gr.

The Levy Economics Institute Working Paper Collection presents research in progress by Levy Institute scholars and conference participants. The purpose of the series is to disseminate ideas to and elicit comments from academics and professionals.

Levy Economics Institute of Bard College, founded in 1986, is a nonprofit, nonpartisan, independently funded research organization devoted to public service. Through scholarship and economic research it generates viable, effective public policy responses to important economic problems that profoundly affect the quality of life in the United States and abroad.

\author{
Levy Economics Institute \\ P.O. Box 5000 \\ Annandale-on-Hudson, NY 12504-5000 \\ http://www.levyinstitute.org
}

Copyright (C) Levy Economics Institute 2012 All rights reserved

ISSN 1547-366X 


\begin{abstract}
This paper examines the underlying dynamics of selected euro-area sovereign bonds by employing a factor-augmenting vector autoregressive (FAVAR) model for the first time in the literature. This methodology allows for identifying the underlying transmission mechanisms of several factors; in particular, market liquidity and credit risk. Departing from the classical structural vector autoregressive (VAR) models, it allows us to relax limitations regarding the choice of variables that could drive spreads and credit default swaps (CDSs) of euro-area sovereign debts. The results show that liquidity, credit risk, and flight to quality drive both spreads and CDSs of five years' maturity over swaps for Greece and Ireland in recent years. Greece, in particular, is facing an elastic demand for its sovereign bonds that further stretches liquidity. Moreover, in current illiquid market conditions spreads will continue to follow a steep upward trend, with certain adverse financial stability implications. In addition, we observe a negative feedback effect from counterparty credit risk.
\end{abstract}

Keywords: Sovereign Debt Crisis; Spreads; CDS; FAVAR Model; Greece and Ireland JEL Classifications: C32, G00, G01 


\section{INTRODUCTION}

Recent events of the euro-area sovereign debt crisis could very well indeed resemble a novel version of ancient tragedy. Euro-area sovereign debt crisis has its origin back in the late 1970s, yet it was in December 2009 that it burst, leading the spreads over bond and credit default swaps (CDSs) to unprecedented levels. It all started with the Greek tragedy that is slowly spreading out to other member states of the Euro-area, such as Ireland and Portugal.

The event that triggered the euro-area sovereign debt crisis can be traced back to the second half of 2007, when the sub-prime crisis sent big waves of distress across the financial markets. But in the second half of 2007 it was still in its early days, as the interest rate on the 10-year maturity Irish sovereign bond was lower than the rate of the German sovereign bond. However, soon into 2008, the Irish rates started rising whereas the German rates remained low. The spreads between Greek and German rates also rose rapidly during the same period, and in fact the Greek spreads lead a race to the top that lead to spreads of above 1000 basis points by summer 2010. Effectively, although only in 2007 , it would have been unheard of to claim that a member state of the euro-group could default ${ }^{1}$, the stratospheric recent Greek spreads show the magnitude of the crisis and the market's perception that Greece faces a very high risk of default.

In the credit risk models literature (see Duffle and Singleton 1999; Hull and White 2000), it is argued that there could be an arbitrage type of relationship between CDSs and credit spreads for a given level of maturity. Duffle (1999) argues that this type of arbitrage would imply that the CDS prices and the credit spreads share a cointegration relationship. A cointegration relationship between the CDSs and European Union (EU) corporate spreads is also reported in Norden and Weber (2004), Zhu (2006), and De Wit (2006). Along these lines, Blanco et al. (2005) show that there is a long run relationship between corporate bonds and CDS markets in the US. Moreover, Blanco et al. (2005) argue that there is an equivalence of CDSs and spreads that dictates a cointegration relationship between the two for corporate bonds in US. ${ }^{2}$

\footnotetext{
${ }^{1}$ The introduction of the euro in 2001 has brought convergence in the spreads of sovereign debts across member states, insinuating a process of economic and financial integration. Alas, by the end of this decade, all have changed and expectations about the future appear gloomy. External shocks, in light of the subprime crisis, play an important role in the widening of sovereign spreads in the eurozone. However, what the Greek sovereign debt crisis reveals is that there are deeply rooted domestic factors that affect spreads. As a result, even if global financial constraints may ease, some Greek spreads would not drop.

${ }^{2}$ One could consider that CDS is an insurance that the holder of, for example, Greek sovereign debt, buys against the event of default. To define a default event is not an easy task. There are various events that could be considered default, such as; bankruptcy, failure to pay, obligation default or acceleration, repudiation or moratorium (for sovereign entities), or restructuring. The last one, restructuring, has steered some heated
} 
We depart from the above literature, as our goal is to contribute by employing, for the first time, factor augmenting vector autoregressive VAR methodology (FAVAR thereafter). The main advantage of FAVAR compared to VAR is that the latter involves only a few variables. Thus, it is certain that the full information context of responses is lost. FAVAR, on the other hand, allows for examining the underlying responses of CDSs and spreads of euro-area sovereign bonds to innovations in a plethora of variables by identifying the full transmission mechanisms at play.

The rest of this article is structured as follows: Section 2 presents a brief literature review of existing studies that have looked at sovereign debt crisis. Section 3 presents some stylized facts of the Greek and Irish sovereign debt crisis, while Section 4 outlines the methodology employed. Section 5 discusses the data, including dates of potential structural breaks. Section 6 presents the results, and finally Section 7 discusses the implications of the results.

\section{STYLIZED FACTS OF THE EURO-AREA SOVEREIGN DEBT CRISIS}

In the third week of July 2007, when the subprime crisis was just placing the world on notice, the yield (interest rate) on the 10-year maturity Irish sovereign bond was lower than the yield on a comparable German sovereign bond. Then, as Irish rates started rising, German rates remained low, with a tendency even to fall as investors sought safety. The spread between Irish and German yields rose rapidly: in the last week of January 2009, the Irish sovereign bond paid about 260 basis points more than the German bond. This spreador risk premium - has fluctuated since, but remains near its highest level since the formation of the eurozone. The size of the spread and, particularly, the swing in a matter of 18 months make Ireland stand out, possibly along with Greece. However, spreads have increased substantially throughout the Euro-area. The spreads are the market's measure of a country's risk of default. While even at the currently elevated levels, the perceived probability of default remains relatively low, markets have determined that higher risk premia are warranted, and more so for some countries.

These striking developments follow several years of tranquility in eurozone bond markets. After the introduction of the euro in January 1999 and up until the subprime crisis hit global financial markets in mid-July 2007, spreads on bonds of eurozone members had

debates in the CDS market. According to the International Swaps and Derivatives Association (ISDA), restructuring is a default event in case that the interest rate or the principal paid at maturity are lowered or delayed. 
moved in a narrow range with only modest differentiation across countries (Figure 1B). The stability and convergence of spreads was considered a hallmark of successful financial integration within the eurozone. The ongoing instability and divergence have raised farreaching questions. Some have even been led to question the viability of the euro as a common currency.

For policymakers, there may be some comfort in the recognition that the wider spreads are due, in the first instance, to external factors. Global financial stress, having infected a widening range of financial asset classes, has also fed through to the bonds of eurozone sovereigns. If the potency of these common external factors is mitigated over time, spreads should come down. But while common factors have played their role, they do not explain the increased dispersion of spreads. Thus, the wider and more diverse spreads could also reflect domestic vulnerabilities. The implication is that higher spreads could persist since the financial vulnerabilities uncovered by the global crisis and weaker growth prospects have the potential to reinforce each other.

Moreover, over the past year, Euro-area sovereign yields have exhibited an unprecedented degree of volatility. In March 2009, the spread between the yield on a 10-year Greek government bond and the yield on a German Bund of equivalent maturity was as high as 280 basis points (bp). By September 2009, the same spread had dropped below $120 \mathrm{bp}$. In January 2010, it had climbed back up to over 380 bp. Alas, things got worst over recent months; in April 2010 the spread reached $670 \mathrm{bp}$ only to climb even higher to the level of 1287 bp in May 2010, the month that the Emergency Financing Mechanism (EFM) and the memorandum of understanding regarding policy conditionality, a joint initiative of the IMF, the EU Commission, and the European Central Bank (ECB) were signed. In July 2010, it registered some decline to $770 \mathrm{bp}$, only to start rising again to above $820 \mathrm{bp}$ in August 2010. Likewise, the credit default swap, the premium investors are willing to pay to insure the same Greek bond against a credit event, follows a similar trajectory as the spread. Note that, although spreads of other Euro-area member states also exhibit a positive slope, no other sovereign bond spread has followed a similar trajectory as the Greek spread.

Moreover, four distinct phases can be identified. July 2007-September 2008 marked the phase of financial crisis build-up, spreads remained within a relatively narrow, albeit widening, range. Between October 2008 and March 2009, there was a systemic outbreak due to the collapse of Lehman Brothers; sovereign spreads started diverging markedly. With the exception of German Bunds, Euro-area government bond yields moved sharply above the swap yield, as problems in the banking sector spilled over to sovereign balance sheets. 
April-September 2009 characterized the systemic response phase; spreads converged, although at wider levels. As financial spillovers were contained and systemic risk subsided, all bond yields fell back closer to the level of the swap yield, particularly those which had gone up considerably in the earlier phase. Finally, beginning in October 2009, rising idiosyncratic sovereign risk led to greater differentiation among countries, with the yields on specific government bonds climbing to record highs. Then, in December 2009, the Greek sovereign debt crisis burst that led spreads and CDSs to unprecedented levels. And while in the beginning it appeared as if the Greek tragedy would expand to other member states of the Euro-area, it soon became clear that the markets perceived the Greek case as in a class of its own with no other members.

Starting with the onset of the subprime crisis in mid-July of 2007 and going through to the rescue of Bear Stearns in mid-March 2008, the variation in sovereign spreads is no longer white noise. The change in spreads is related to "global factors," both flight to quality (captured by the response to changes in the German Bund yield) and global financial risk (as proxied by the change in the CDS spreads of US banks). Thus, the global factors that were seen as associated with change in spreads in the overall regression are seen to dominate in this first phase of the crisis. Two implications follow. First, global risk aversion, which was spreading to various asset classes, became a perceptible factor in the sovereign bond markets - what is remarkable is that this occurred so early in the evolution of the crisis. Second, at least as first approximation, these factors influenced all countries equally (interacting them with country dummies did not lead to clear results), and, as such, there was a general tendency for spreads to rise with minimal country differentiation.

Starting with the rescue of Bear Stearns, three trends are noticeable. First, the influence of the identifiable global factors steadily declined. Similarly, the (partial) correlation between the change in CDS spreads of US banks and the change in eurozone sovereign spreads declined. Second, external factors did play a role in the post-Bear Stearns phase, but this was so in a less pinpointed sense and reflected after Lehman in a general upward pressure on spreads, proxied by the dummy for that last period. Finally, the big change in the post-Bear Stearns phase was the important role of domestic factors, represented by the market's assessment of financial sector prospects. This was the source of spreads' differentiation.

Thus, Bear Stearns marked an important turning point in the crisis as seen through the lens of eurozone sovereign spreads. The debate on whether or not Bear Stearns should have been bailed out has hinged on the risk of moral hazard-critics have warned that bank 
managers will become even more irresponsible, while proponents of the rescue have been focused on the stability of the financial system. Even as that debate plays out, the data show that there was an immediate impact. The implicit assumption that systemically important banks would typically be bailed out was converted into an explicit and close tie between banks and the dynamics of public finance. Interestingly, the Bear Stearns rescue initially generated optimism that the financial sector had become safer, and sovereign spreads fell. However, that optimism lasted briefly. Two months later, by mid-May 2008, the financial sector was being perceived as increasingly weaker and sovereign spreads were, once again, on the rise. Thus, although these dynamics became more pronounced after Lehman, the process had already commenced some months earlier.

The final phase of these developments followed the nationalization of Anglo Irish Bank. Relative to Bear Stearns, the other bookend of this story, Anglo Irish is a small bank and its nationalization likely did not carry the same market significance as the Bear Stearns rescue. Moreover, the Anglo Irish nationalization came at a time when the global "mood music" was particularly gloomy. But, it is the case that markets moved rapidly. Viewed by the authorities as systemically important to the Irish financial system, the beleaguered Anglo Irish was nationalized late on the evening of Thursday, January 15, 2009. On Friday morning, the share prices of the other major Irish banks-Allied Irish Banks and the Bank of Ireland-fell sharply, by 12.9 and 13.3 percent, respectively. This was the trigger to a new burst of anxiety as financial stocks got hammered and sovereign spreads soared, in Ireland and elsewhere in the eurozone. In the terminology of this paper, the Irish "F-index," i.e., the ratio of its financial sector equity index to the overall equity index, had experienced a modest revival after Christmas, rising from 21 in the week starting December 26, 2008 to 24 in the week starting January 9, 2009 (despite the sharp fall in financial sector stocks on the Friday of that week). The F-index then fell back 21 in the week starting January 16 and with that fall, Irish sovereign spreads jumped by sizeable 32 basis points, almost 20 percent over the previous week's average of 142 basis points. In the week starting January 23, the F-index dived to 14 and the sovereign spreads rose a stunning 80 basis points to 260 basis points, almost 50 percent over the previous week's average.

The same story played itself out through much of the eurozone. As in Ireland, the Findex had stabilized elsewhere. After Christmas, the average F-index in the other nine eurozone countries in my sample had been stable - though, relative to Ireland, at the much higher level of 77 . This index fell by 2 points in the week starting January 16 and spreads 
jumped by 16 basis points, from 95 to 111 basis points. Then a further fall of the F-index by 3 points was associated with a rise in spreads to 123 basis points.

Thus, a significant shift occurred in the second half of January 2009 as the financial sector appeared to weaken further and sovereign spreads climbed rapidly. It was as if some threshold had been crossed, triggering a surge in spreads. However, it is also evident that countries were differentiated even in the midst of these sweeping changes. To explore country differences, the data for the estimations presented in Table 5 is extended to include weeks of January 16 and January 23. Recognizing that the developments during this period were special, I add a post-Anglo Irish dummy for these two weeks. This dummy is interacted in column 1 with the level of the F-index. The hypothesis is that spreads moved not just in response to the changes in the F-index as had been the case since the Bear Stearns rescue. Rather there was an accelerated transition to higher spreads responding to the level of the Findex, as if markets were recalibrating to the cumulative deterioration of financial sector prospects.

Thus, in the last two weeks of January, an ongoing process was accelerated. While in the period leading up to mid-January, changes in financial vulnerability were followed by a rise in spreads, in the final weeks of January, spreads responded to the level of vulnerability. Markets evidently decided that they had some catching up to do. And that catch-up had a tangible goal in some countries. For the most part, spreads on banks' own debt had been higher than on sovereign spreads from the start of the subprime crisis. This was true for much of the period and for most countries. Only in Italy and Portugal, bank and sovereign spreads had converged, with sovereign spreads actually rising above bank spreads sometime after the fall of Lehman Brothers. The last two weeks of January saw a wider convergence of spreads: even as sovereign spreads rose, bank spreads fell as if the sovereign had taken on the risk of the financial sector. After those two dramatic weeks, bank spreads had once again typically been higher than sovereign spreads. However, the significance of the last two weeks of January appears to be that sovereign and bank risks caught up with each other and tended thereafter to exhibit more co-movement rather than the lagged relationship observed in the previous months.

Despite this evidence, to this day there is not a comprehensive account of what has happened in the market with reference to the euro-area sovereign debt crisis. Financial market theory suggests that CDS spreads and corporate bond spreads for the same entities are bound by no-arbitrage conditions. By ignoring differences in liquidity and assuming that the maturity of the corporate debt equals that of the CDS, an investor who acquires a 
corporate bond and buys protection for the same reference entity in the CDS market should be hedged against the default of this particular firm. The implied no-arbitrage assumption between the two markets suggests that the price of buying such a protection against default in the CDS markets should equal the observed corporate bond yield spread.

A long-term relationship between the two credit markets for European entities was documented by Norden and Weber (2004), Zhu (2006) and De Wit (2006). Overall, most previous studies found the existence of a long-term (co-integrating) relationship between the two markets for the bulk of the entities examined. The existence of a long-run relationship between the two markets does not, however, exclude short-run arbitrage opportunities. Levin et al. (2005) argue that market frictions are the main cause of non-zero CDS-bond spread basis. The authors argue that these market frictions are caused by systematic and idiosyncratic factors. Forte and Pena (2006) show that, in terms of price discovery, stock markets lead both bond and CDS markets. Concentrating on the CDS and bond markets, Doetz (2007) studies the price discovery in these two markets in a time-variant context. The results indicate that although the CDS market slightly dominates the price discovery process, its contribution fell significantly during the 2005 turbulence when General Motors and Ford were downgraded by the rating agencies from investment grade to "junk" grade.

\section{THE MARKET OF CREDIT DEFAULT SWAPS AND CREDIT SPREADS: HOW THEY OPERATE}

In a credit default swap, the protection seller agrees to pay the default payment to the protection buyer if a default event has happened before maturity of the contract. If there is no default event before maturity, the protection seller pays nothing. The protection seller charges a fee for the protection. This is typically a constant quarterly fee paid until default or maturity, whichever is first. Should a default event happen, the accrued fee is also paid. We refer to the annualized fee as the credit default swap price. The default payment is either repayment at par against physical delivery of a reference asset (physical settlement) or the notional amount minus the post-default market value of the reference asset determined by a dealer poll (cash settlement).

Physical delivery is the dominant form of settlement in the market. A broad set of debt obligations is deliverable as long as they rank pari passu with the senior unsecured indebtedness of the reference entity. Default events for CDSs might include some or all of 
the following: bankruptcy, failure to pay, obligation default or acceleration, repudiation or moratorium (for sovereign entities), and restructuring.

The first four are not contentious, although the evolving International Swaps and Derivatives Association (ISDA) documentation has dropped events obligation default or acceleration and repudiation or moratorium in some jurisdictions since they have been deemed subsumed by events bankruptcy — failure to pay. Restructuring has been and remains a source of controversy in the CDS market. The 1999 ISDA documentation defines restructuring to constitute a default event if either the interest rate or principal paid at maturity are reduced or delayed, if an obligation's ranking in payment priority is lowered, or if there is a change in currency or composition of any payment (excluding adoption of the euro by a member state of the European Union). The key problem is that not all deliverable assets necessarily become due and payable should restructuring occur, and it is conceivable that some deliverable obligations will be cheaper than others. This is likely to be particularly acute where deliverable assets include very long-dated or convertible bonds that often trade at a discount to shorter-dated straight bonds. This means that where there is a non-negligible probability of a restructuring that falls short of making all debt due and payable and where some obligations trade at a substantial discount to others, then a physically-settled CDS price also contains a cheapest-to-deliver (CTD) option and is not a pure measure of credit risk. European CDSs traded on the basis of this definition throughout our data sample. US CDSs have been subject to a Modified Restructuring definition since May 11, 2001 that, among other aspects, restricted the scope of deliverable assets and specifically prevents the delivery of very long-dated bonds. This reduces the value of the delivery option in US default swaps.

There is a large and growing literature on the pricing of credit risk, within which two approaches dominate. Structural models are based on the value of the firm and are usually derived from Merton (1974). In this class of models, default occurs when the process describing the value of the firm hits a given boundary. Black and Cox (1976), Geske (1977) and Longstaff and Schwartz (1995) are three of many important references. Das (1995) and Pierides (1997) apply structural models to the pricing of credit derivatives. The second approach, usually termed reduced-form or intensity-based models, instead assume that the timing of default is specified in terms of a hazard rate. Leading reduced-form frameworks would include Jarrow and Turnbull (1995), Jarrow, Lando and Turnbull (1997) and Duffie and Singleton (1999). Das and Sundaram (1998), Duffie (1999) and Hull and White (2000) apply reduced-form models to credit derivative pricing issues. Both structural and reduced- 
form approaches are very comprehensively surveyed in Lando (1997) and Schonbucher (2000).

The spread on par fixed-coupon risky bond over the par fixed-coupon risk-free bond exactly equals the CDS price if the payment dates on the CDS and bond coincide and recovery on default is a constant fraction of face value (Houweling and Vorst 2002). Alternatively, with a flat risk-free curve and constant interest rates, the arbitrage is perfect if the payout from a CDS on default is the sum of the principal amount plus accrued interest on a risky par yield bond times one, minus the recovery rate (Hull and White 2000). As noted above, however, the payout from a CDS usually equals the principal amount minus the recovery rate times the sum of principal and accrued interest on the reference obligation. Nevertheless the referenced papers show that the arbitrage is reasonably accurate for assets trading close to par when interest rates are not high and yield curves are relatively flat. Three other considerations are relevant. First, physically-settled CDS prices, especially for European entities, may contain CTD options as noted above. Other things equal, this will lead CDS prices to be greater than the credit spread.

Unfortunately, it is impossible to value this option analytically since there is no benchmark for the post-default behavior of deliverable bonds, and hence we cannot simply subtract its value from the CDS price. Second, the arbitrage relationship that should keep the two prices together can rely on short selling the cash bond. This is not always costless and indeed is not always even possible in illiquid corporate bond markets. If the repo cost of shorting the cash bond is significant, then the credit spread we have computed (bond yield minus the risk-free rate) underestimates the true credit spread (bond yield minus risk-free rate plus the repo cost). Again, the CDS price will tend to be greater than the measured credit spread (Duffie 1999). Although both the CTD option and non-zero repo costs can occur independently, when a firm's credit risk increases, the demand to short sell the bond rises, driving up the repo cost, and the value of the CTD option rises. Neither market then provides a pure measure of credit risk. Quantifying these two factors is difficult in the absence of reliable repo cost data or a valuation model for the option. However, since both the repo cost and the option value are bounded at zero, we can say that the CDS price is an upper limit on the price of credit risk while the credit spread provides a lower limit.

Third, liquidity premia exist in both the cash bond and CDS markets. The cash bond market is often described as relatively illiquid, particularly outside the United States. Movements in liquidity premia may explain a large proportion of the total variation in credit spreads (Collin-Dufresne, Goldstein, and Martin 2001). The CDS market is still relatively 
small despite its rapid recent growth, and so demand-supply imbalances can often cause short-term price movements unrelated to default expectations.

\section{METHODOLOGICAL FRAMEWORK OF THE FAVAR}

Following Bernanke et al. (2005), let $\mathrm{S} t$ be a $M \times 1$ vector of sovereign debt spreads and CDSs assumed to drive the underlying dynamics of the sovereign debt. The main point of this paper is to reveal the underlying structural relationships among these spreads. In the current FAVAR modelling, we assume that there exists additional information that is within a $K \times 1$ vector of unobserved factors, $\mathrm{F} t$, where $K$ is "small." These unobserved factors could be market specific, such as migration risk, which is credit downgrading, and counter party risk or reflecting numerous economic factors, such as growth rates. Last, there is also a vector of some known, observable $Z_{t}$ variables that could have an impact on spreads. The FAVAR model is:

$$
S_{i t}=\beta_{0 i}+\beta_{i} F_{t}+\beta_{i} Z_{t}+\varepsilon_{i t}
$$

where $\mathrm{F}$ is an $N \times K$ matrix of factor loadings, $\mathrm{Z}$ is $N \times M$, and the $N \times 1$ vector of error terms $\varepsilon$ are mean zero and will be assumed either normal and uncorrelated or to display a small amount of cross-correlation, depending on whether estimation is by likelihood methods or principal components.

Assume that the joint dynamics of $(\mathrm{S} t, \mathrm{Z} t)$ are given by the following transition equation:

$$
\left|\begin{array}{l}
S_{t} \\
Z_{t}
\end{array}\right|=\Phi(L)\left|\begin{array}{l}
S_{t-1} \\
Z_{t-1}
\end{array}\right|+v_{t}
$$

where $(\mathrm{S} t, \mathrm{Z} t)$ is a vector of spread and $\mathrm{Z}$ variables that could have an impact, $\Phi(L)$ is a conformable lag polynomial of finite order $d$, which may contain a priori restrictions as in the structural VAR literature. The error term $v t$ is mean zero with covariance matrix $Q$.

The above equation is a VAR in $(\mathrm{S} t, \mathrm{Z} t)$. It might be interpreted as the reduced form of a linear sovereign debt model involving both observed and unobserved variables. This system reduces to a standard VAR in $\mathrm{S} t$ if the terms of $\Phi(L)$ that relate $\mathrm{S} t$ to $\mathrm{Z} t-1$ are all zero.

Because the FAVAR model nests standard VAR analyses, estimation of this equation allows for easy comparison with existing VAR results, and provides a way of assessing the marginal contribution of the additional information contained in $\mathrm{Zt}$. We assume that the informational time series $\mathrm{Zt}$ are related to the unobservable factors $\mathrm{Ft}$ and the observed variables St. 
This equation captures the idea that both $\mathrm{F} t$ and $\mathrm{Z} t$, which in general can be correlated, represent common forces that drive the dynamics of St. Conditional on St, the Zt are thus noisy measures of the underlying unobserved factors Ft. St depends on the contemporaneous levels of independent variables (factors), while $\mathrm{Zt}$ is interpreted as including a number of certain lags of the fundamental factors.

\section{THE DATA SET}

The sovereign spread for Greece and Ireland at time " $\mathrm{t}$ " $\left(\operatorname{Sr} d_{t}\right)$ is measured as the difference between secondary-market yield on the country's 5-year bond and the swaps yield. On the other hand, the CDS for 5-year maturity is also spread with respect to the swaps yield. CDS reflects an insurance premium paid by the market's participants against default. To this end, CDS provides a forward looking picture of spreads. Both the spread and the 5-year maturity CDS are derived from Bloomberg.

We opt for the following factors to examine their impact on sovereign CDS spreads as well as in sovereign bond spreads. First, we take proxies for credit risk: i) The risk-free rate; as the Merton (1974) model shows that changes in the risk-free rate in general are negatively related to credit spreads. A rising risk-free rate decreases the present value of the expected future cash flows of sovereign bonds and the price of the put option decreases. As a Euro-wide homogeneous proxy, we use the Euribor three-month short rate. ii) Corporate CDS premium (iTraxx); as credit spreads compensate investors for more than pure expected loss, this premium is a measure of aggregate credit market developments, namely the iTraxx Main Investment Grade index. The premium on this CDS index should also contain a proxy for investors' overall appetite for credit risk. Second, we opt for a proxy of country's public debt. In structural models of sovereign credit risk (Gapen et al. 2005), a firm's leverage defined as the ratio of debt to its assets is a major risk factor. This risk factor is also acknowledged in a fiscal policy perspective as the EU's Stability and Growth Pact aims to cap a country's total debt at 60 percent of its GDP. As a proxy, we use a country's total outstanding bonds relative to its GDP. This choice of variable is motivated by data availability, as the amount of bonds outstanding is available in Bloomberg on a monthly frequency. We expect that higher debt increases CDS spreads. For sovereign bonds, in a market with elastic demand, this variable reflects bond market liquidity because a larger bond market generally contributes to lower transaction costs. However, if overall supply of new issuance exceeds existing demand, then there could also be an adverse impact on bond 
market liquidity. We expect the second effect to be primarily relevant for bond spreads. Last, we also employ the spread between Euribor-Eurepo. This variable is expected to assert a positive impact on the spreads. When the repo rate is lower than the Euribor, it is costly to implement a positive basis trade, which implies short-selling the underlying bond obtained via repurchase agreement and selling protection.

\section{EMPIRICAL RESULTS}

\subsection{Empirical Estimation}

The underlying VAR of our model takes the following form:

$$
S_{t}=\sum A S_{t-1}+u_{t}
$$

Where St represents the spreads and CDSs for Greece and Ireland. To simplify notation, we include in $\mathrm{S}$ vector also the $\mathrm{Z}$ variables, namely the Euribor three-month short rate, Europe three-month repo, the corporate CDS premium (iTraxx), country's total outstanding bonds relative to its GDP, and the spread between Euribor-Eurepo.

From the above VAR we get the following FAVAR:

$$
\left|\begin{array}{l}
S_{t} \\
F_{t}
\end{array}\right|=\Phi(L)\left|\begin{array}{l}
S_{t-1} \\
F_{t-1}
\end{array}\right|+v_{t}
$$

Where $F t=\left(F_{1 t} ; F_{2 t}\right)$ are two factors we get from the following steps. In the first of the steps, we regress the $\mathrm{S}$ to $\mathrm{Z}$ as $Z_{i t}=\Lambda_{i} S_{t}+\varepsilon_{i t}$, where $\Lambda$ is a latent variable. In this paper, we employ two latent variables, thus the unobserved factors are two. We construct the factors $F$ from $Z_{i t}$ - $\Lambda_{i} S_{t} \mathrm{~N}$ by applying the principal component method. In the second step, we impose Choleski ordering and employ the unobservable factor $F$ from the first step in a simple recursive framework. In the ordering, we opt to first insert spread and CDS. The remaining variables that are observables are assumed to respond to spread and CDS, that is, to sovereign debt crisis variables. Two lags are employed in the FAVAR.

\subsection{FAVAR Specification}

Next, we report the FAVAR specifications for Greece and Ireland. It appears that most factors are jointly significant. 
Table 1 FAVAR specifications for Greece

\begin{tabular}{|l|l|l|l|l|l|l|l|}
\hline & CDS & Spread & $\begin{array}{l}\text { Euribor } \\
\mathbf{3 M}\end{array}$ & $\begin{array}{l}\text { Eurepo } \\
\mathbf{3 M}\end{array}$ & iTraxx & debt & $\begin{array}{l}\text { Euribor- } \\
\text { Eurepo }\end{array}$ \\
\hline Adj. $\mathbf{R}^{\mathbf{2}}$ & 0.4842 & 0.6806 & 0.55119 & 0.7642 & 0.1211 & 0.4842 & 0.6806 \\
\hline S.E. & 0.0677 & 0.0134 & 0.30860 & 0.1642 & 0.3711 & 0.0677 & 0.0134 \\
\hline $\mathbf{X}^{\mathbf{2}}$ & 18.09 & 14.097 & 12.365 & 14.066 & 10.011 & 16.089 & 17.047 \\
\hline & & & & & & & \\
\hline
\end{tabular}

Note: CDS counts for the CDSs of Greece, Spread for Greece.

Table 2 FAVAR specifications for Ireland

\begin{tabular}{|l|l|l|l|l|l|l|l|}
\hline & CDS & Spread & $\begin{array}{l}\text { Euribor } \\
\mathbf{3 M}\end{array}$ & $\begin{array}{l}\text { Eurepo } \\
\mathbf{3 M}\end{array}$ & iTraxx & debt & $\begin{array}{l}\text { Euribor- } \\
\text { Eurepo }\end{array}$ \\
\hline Adj. $\mathbf{R}^{\mathbf{2}}$ & 0.1044 & 0.3420 & 0.57531 & 0.1445 & 0.2910 & 0.10442 & 0.3423 \\
\hline S.E. & 0.0809 & 0.04097 & 0.03653 & 0.0616 & 0.011 & 0.0809 & 0.0407 \\
\hline $\mathbf{X}^{\mathbf{2}}$ & 13.44 & 10.6420 & 15.7531 & 14.145 & 18.291 & 14.442 & 19.423 \\
\hline & & & & & & & \\
\hline
\end{tabular}

Note: CDS counts for the CDSs of Ireland, Spread for Ireland.

\subsection{FAVAR Impulse Response Functions}

Next, we report the impulse response function (IRF) from the FAVAR. First we look at a shock on the risk-free rate, as we expect that changes in the risk free rate, in general, to be negatively related to sovereign debt spreads. ${ }^{3}$ IRFs, both Greece and Ireland, confirm this. Thus, a shock in the risk free rate, for example an increase in risk-free rate, would decrease the present value of the expected future cash flows of sovereign debt, and thus should lower the credit spread.

Figure 1 Impulse response of Greek spread over swaps to Euribor 3M

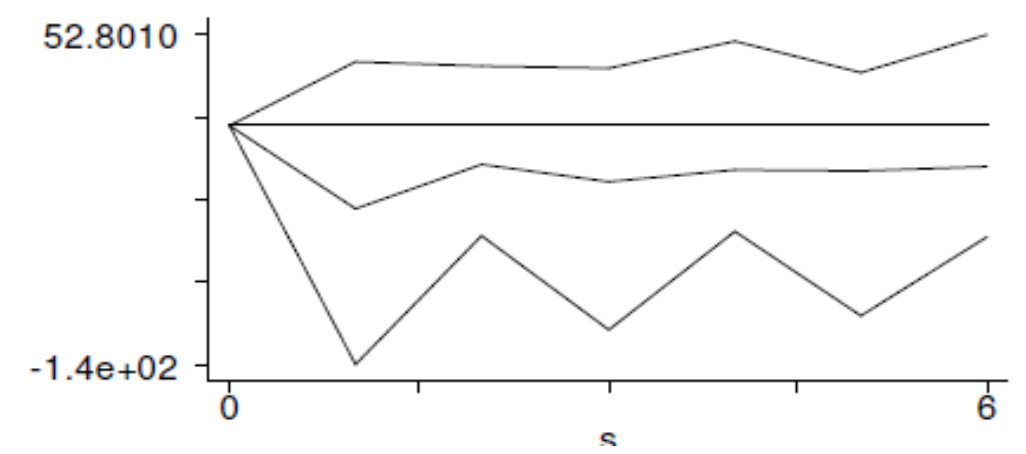

\footnotetext{
${ }^{3}$ Similar IRFs, as appear in this section, are reported in the Appendix with respect to the response of CDS.
} 
Figure 2 Impulse response of Irish spread over swaps to Euribor 3M

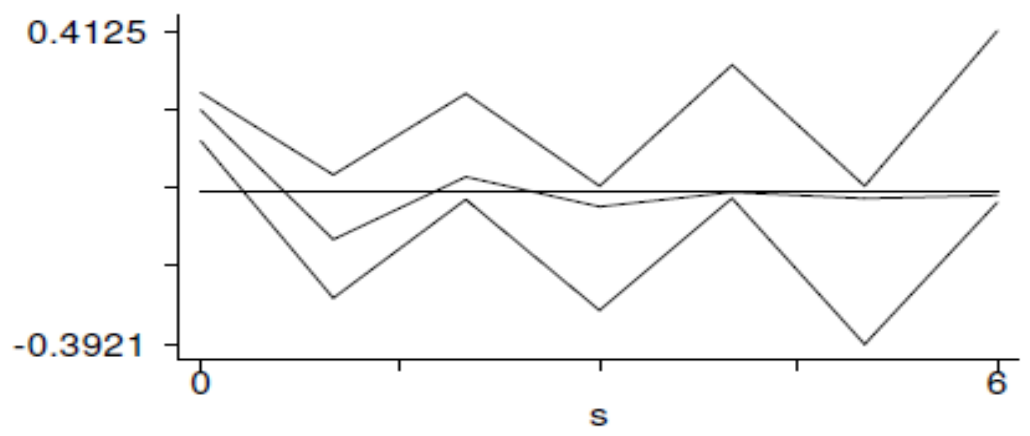

The shock in the Eurepo has a positive impact on the spread. An increase in repo rate means that it is costly to implement a positive basis trade, and this would raise the spread of sovereign debt contributing in financial instability.

Figure 3 Impulse response of Greek spread over swaps to Eurepo 3M

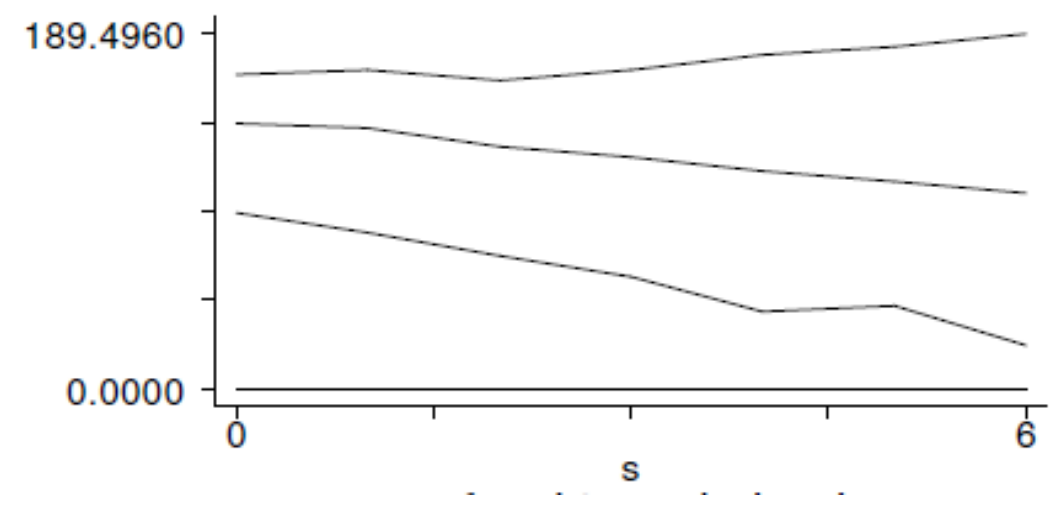

Figure 4 Impulse response of Irish spread over swaps to Eurepo 3M

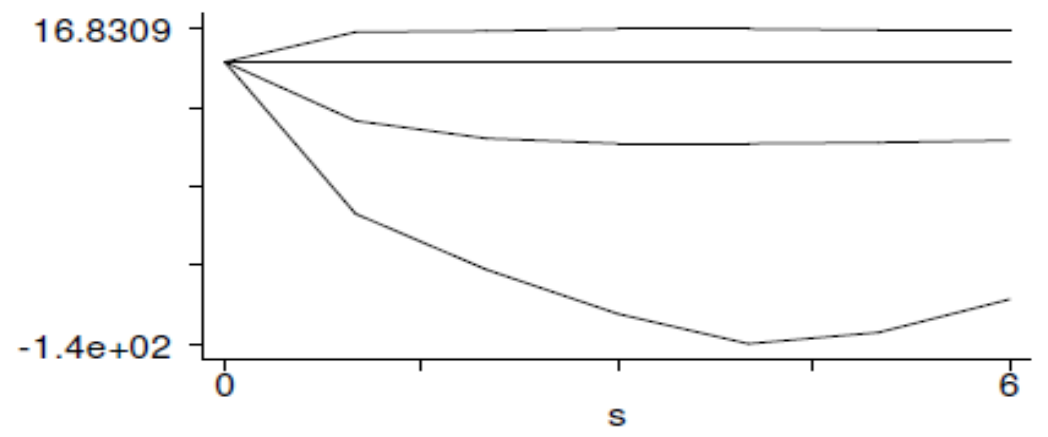

We also employ a shock in corporate CDS premium, which is iTraxx. The response of spread on a shock in corporate CDS is positive, though it declines over time, reflecting investors' overall appetite for credit risk. 
Figure 5 Impulse response of Greek spread over swaps to iTraxx

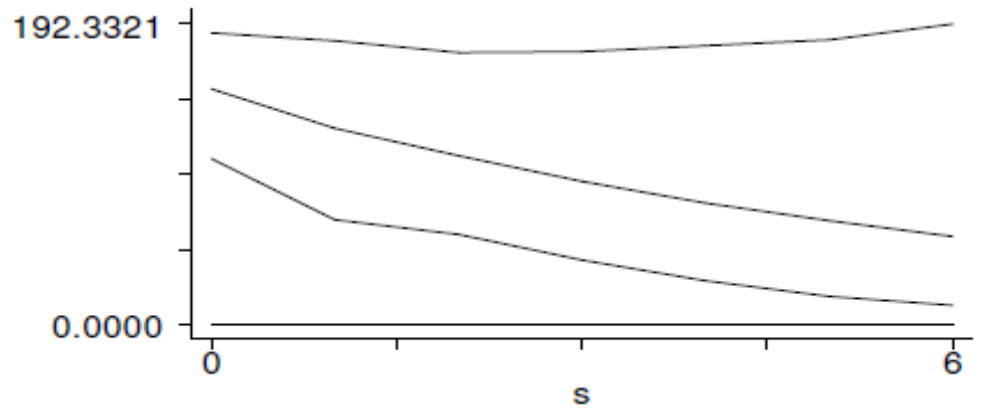

Figure 6 Impulse response of Greek spread over swaps to iTraxx

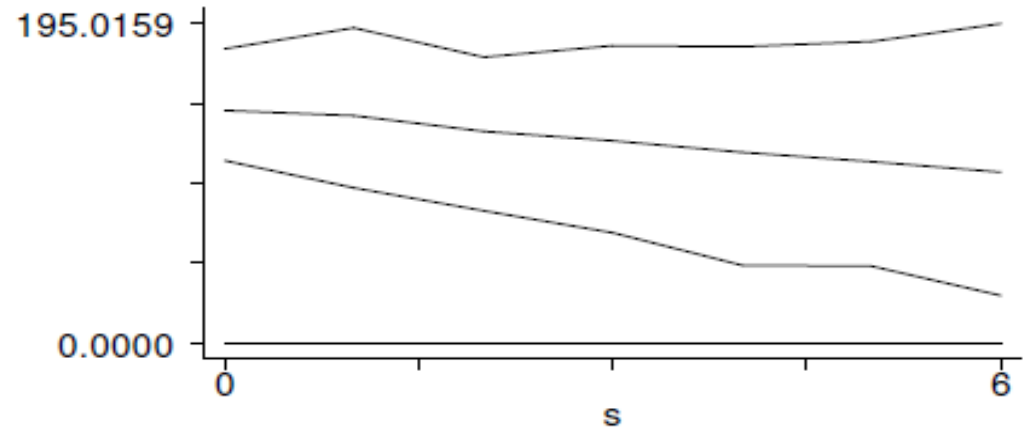

An important transmission channel is the fiscal imbalances. We find that higher debt increases spreads of sovereign debt in the first period or so, but then it asserts a negative impact for Greece. ${ }^{4}$ Effectively, sovereign issuance of Greek bonds is facing an elastic demand, and shows the limits of bond market liquidity. Thus, as overall supply of new sovereign issuance bonds exceeds existing demand, and as a result it has an adverse impact on bond market liquidity.

Figure 7 Impulse response of Greek spread over swaps to debt

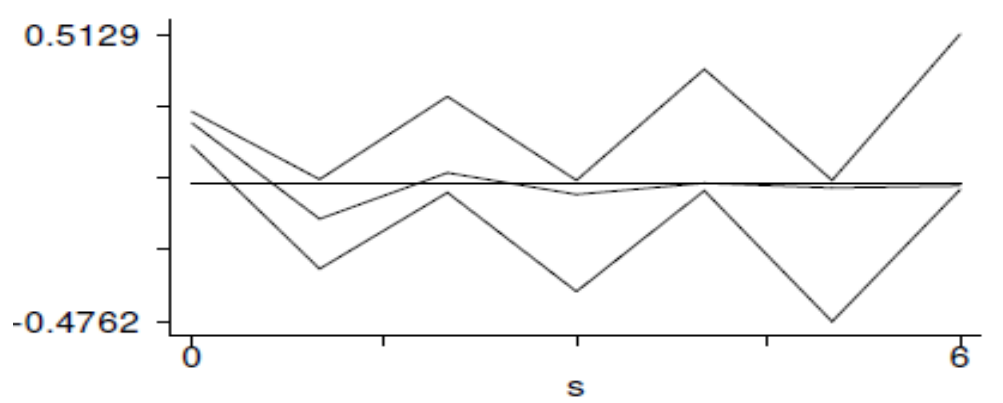

\footnotetext{
${ }^{4}$ For Ireland, we get a different picture, as the fiscal transmission mechanism asserts a positive impact on spreads.
} 
Figure 8 Impulse response of Irish spread over swaps to debt

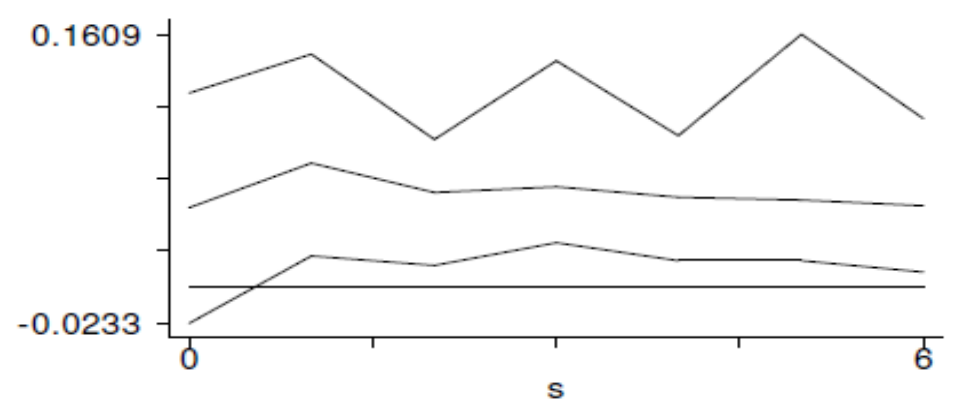

We also employ the difference between Euribor-Eurepo. The results show that the response of spreads to a shock in the difference between Euribor-Eurepo is positive throughout the period. As the repo rate is lower than the Euribor, it becomes costly for the market participants to arbitrage by short-selling the underlying bond obtained via repurchase agreements and selling protections in the form of CDS.

Figure 9 Impulse response of Greek spread over swaps to the difference between Euribor and Eurepo 3M

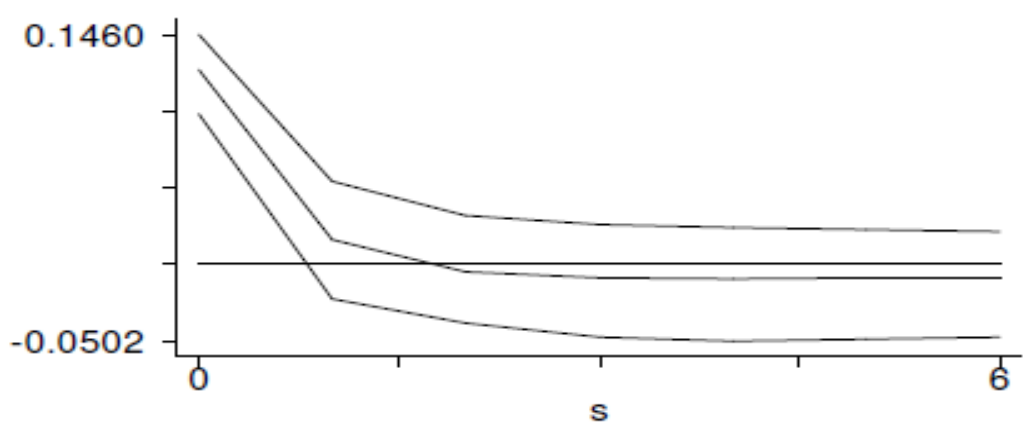

Figure 10 Impulse response of Irish spread over swaps to the difference between Euribor and Eurepo 3M.

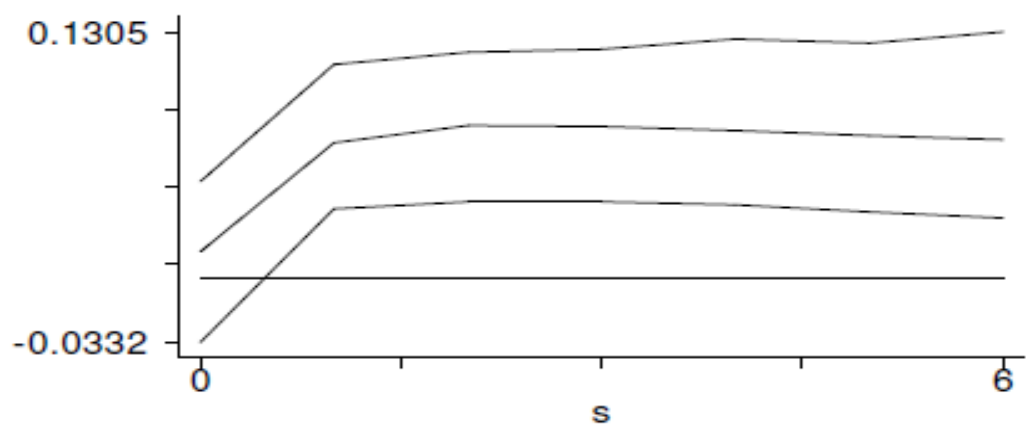

Overall, the above results show negative feedback effects from counterparty risk, which is defined as creditworthiness of loans providers, such as the EU member states and the IMF, that impact spreads and CDS dynamics. Note, however, that as liquidity risk increases across 
the euro-area in terms of the available funds, it becomes an issue and essentially default protection against default is no longer valuable.

\section{Conclusion}

Duffie (2010) argues that high CDS for corporate bonds in the US after the credit crunch persisted due to severe depletion of capital that in turn caused large distortions in arbitrage, and to a lesser extent due to counterparty risk or default risk. This could be the case as the current FAVAR analysis shows for the euro-area sovereign debt crisis.

Both Greece and Ireland appear to be within a cyclone, as in the present conditions of debt crisis markets are short of capital, whilst in parallel banks are undercapitalised. This depletion of capital poses a great challenge for euro-area sovereigns with large fiscal imbalances that, in turn, result in high costs to hold such sovereign bonds due to high haircuts in the repo markets (Mitchell and Pulvino, 2010).

Thus, deteriorating market liquidity appears to be the driving force behind high sovereign spreads and CDS. In terms of economic policy, given the current degree of markets' pessimism regarding the prospects of public finances in the euro-area and worldwide, one could advise to enhance the scope and the scale of monetary policy. 


\section{REFERENCES}

Bernanke, B., J. Boivin and P. S. Eliasz. 2005. "Measuring the Effects of Monetary Policy: A Factor-augmented Vector Autoregressive (FAVAR) Approach.” The Quarterly Journal of Economics 120: 387-422.

Black, F., and C. Cox. 1976. "Valuing Corporate Securities: Some Effects of Bond Indenture Provisions.” Journal of Finance 31(2): 351-367.

Blanco R., S. Brennan, and I.W. Marsh. 2005. “An Empirical Analysis of the Dynamic Relationship between Investment-Grade Bonds and Credit Default Swaps.” Journal of Finance 60(5): 2255-2281.

Collin-Dufresne P., R. Goldstein, and J. S. Martin. 2001. "The Determinants of Credit Spread Changes." Journal of Finance 56(6): 2177-2207.

Das, S. R. 1995. “Credit Risk Derivatives.” Journal of Derivatives 2(3): 7-23.

Das, S. R. and R. K. Sundaram. 1998. "A Direct Approach to Arbitrage-Free Pricing of Credit Derivatives.” Working Paper No. 6635. Cambridge, MA: National Bureau of Economic Research.

De Wit, J. 2006. "Exploring the CDS-Bond Basis." Research Series. National Bank of Belgium.

Doetz, N. 2007. "Time-Varying Contributions by the Corporate Bond and CDS Markets to Credit Risk Price Discovery.” Discussion Paper Series 2: Banking and Financial Studies No 08/2007. Frankfurt, Germany: Deutsche Bundesbank.

Duffie, D. 1999. “Credit Swap Valuation.” Financial Analysts' Journal 83: 635-665.

—. 2010. "Presidential Address: Asset Price Dynamics with Slow-Moving Capital." Journal of Finance 65(4): 1237-1267.

Duffie, D. and K. J. Singleton. 1999. "Modelling the Term Structures of Defaultable Bonds." Review of Financial Studies 12: 687-720. 
Forte, S. and J. I. Pena. 2006. "Credit Spreads: Theory and Evidence about the Information Content of Stocks, Bonds and CDSs." Working Paper 06-33, Business Economic Series. Madrid, Spain: Department of Economics, University of Carlos III de Madrid.

Gapen, M., D.F. Gray, C. H. Lim, and Y. Xiao. 2005. "Measuring and Analyzing Sovereign Risk with Contingent Claims.” IMF Working Paper 2005/155.

Geske, R. 1977. "The Valuation of Corporate Liabilities as Compound Options.” Journal of Financial and Quantitative Analysis 12(4): 541-552.

Houweling, P and T. Vorst. 2002. “An Empirical Comparison of Default Swap Pricing Models.” Unpublished manuscript. Rotterdam, Netherlands: Erasmus University.

Hull J. C., M. Predescu, and A. White. 2005. "Bond Prices, Default Probabilities and Risk Premiums." Journal of Credit Risk 1: 53-60.

Hull, J. C. and A. White. 2000. "Valuing Credit Default Swaps I: No Counterparty Default Risk." Journal of Derivatives 8(1): 29-40.

Jarrow, R. and S. Turnbull. 1995. "Pricing Derivatives on Financial Securities Subject to Credit Risk." Journal of Finance 50(1), 53-86.

Jarrow, R., D. Lando, and S. M. Turnbull. 1997. "A Markov Model for the Term Structure of Credit Risk Spreads.” The Review of Financial Studies 10(2): 481-523.

Lando, D. 1997. "Modelling Bonds and Derivatives with Default Risk.” In M. Dempster and S. Pliska (eds.), Mathematics of Derivatives Securities. Cambridge, UK: Cambridge University Press.

Levin, A. T., A. Onatsaki, J. C. Williams, and N. Williams. 2005. "Monetary Policy under Uncertainty in Micro-Founded Macroeconometric Models.” In NBER Macroeconomics Annual 2005. Cambridge, MA: MIT Press.

Longstaff, F.J. and E. Schwartz. 1995. "A Simple Approach to Valuing Risky, Fixed and Floating Rate Debt.” Journal of Finance 50(3): 789-821.

Merton, R. C. 1974. "On the Pricing of Corporate Debt: The Risk Structure of Interest Rates." Journal of Finance 29(2): 449-470. 
Mitchell, M. and T. Pulvino. 2010. “Arbitrage Crashes and the Speed of Capital.” Mimeo.

Norden, L. and M. Weber. 2004. "The Co-Movement of Credit Default Swap, Bond and Stock Markets: An Empirical Analysis.” Working Paper 2004/20. Frankfurt, Germany: Center for Financial Studies.

Pierides, Y. A. 1997. "The Pricing of Credit Risk Derivatives.” Journal of Economic Dynamics and Control 21(10): 1579-1611.

Schonbucher, P. J. 2000. “A Libor Model with Default Risk.” Bonn Economics Discussion Paper. Bonn, Germany: University of Bonn.

Zhu, H. 2006. "An Empirical Comparison of Credit Spreads between the Bond Market and the Credit Default Swap Market.” Journal of Financial Services Research 29(3): 211-235. 


\section{APPENDIX}

Appendix Figure 1 Impulse response of Greek CDS over swaps to Euribor 3M

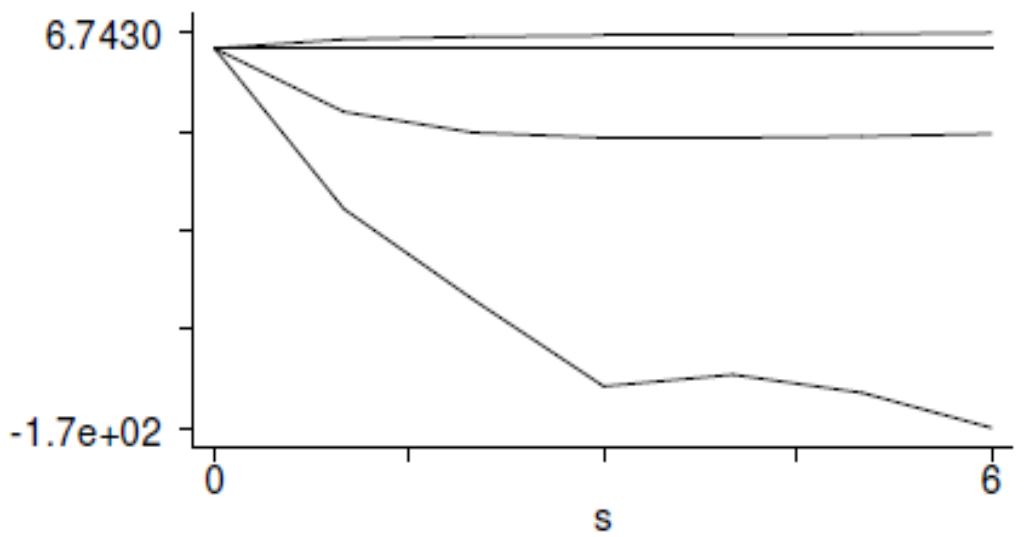

Appendix Figure 2 Impulse response of Irish CDS over swaps to Euribor 3M

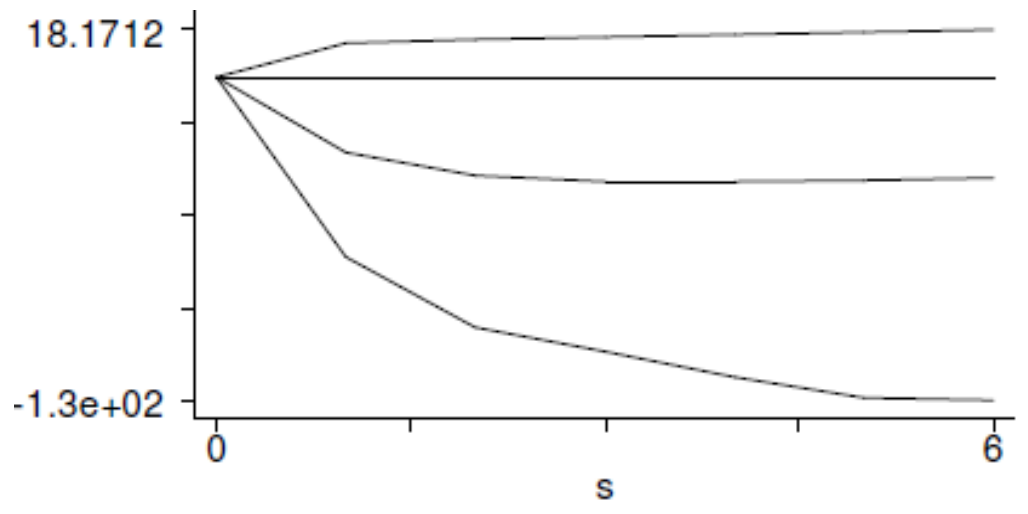

Appendix Figure 3 Impulse response of Greek CDS over swaps to Eurepo 3M

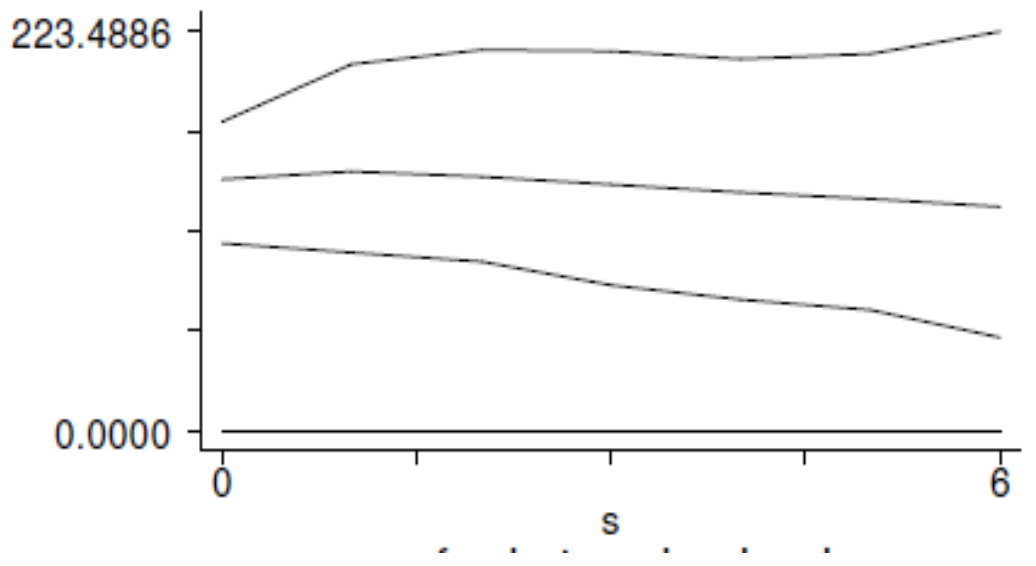


Appendix Figure 4 Impulse response of Irish CDS over swaps to Eurepo 3M

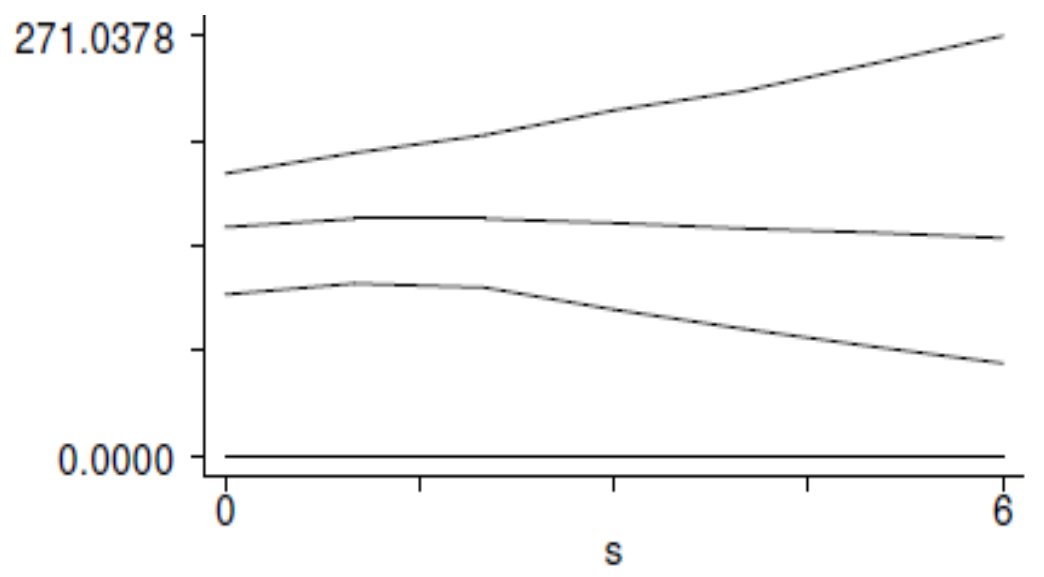

Appendix Figure 5 Impulse response of Greek CDS over swaps to iTraxx

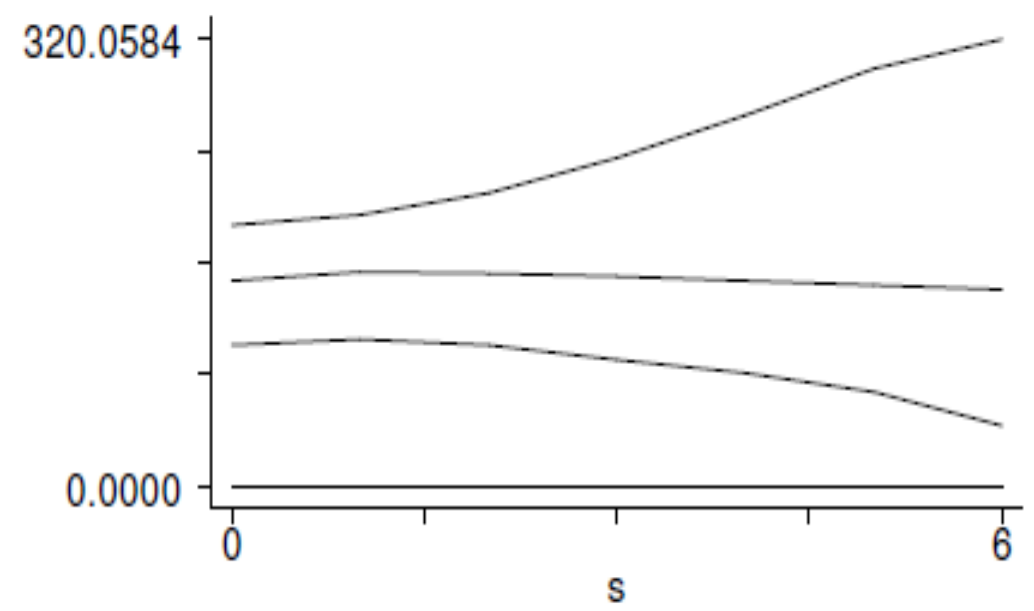

Appendix Figure 6 Impulse response of Greek CDS over swaps to iTraxx

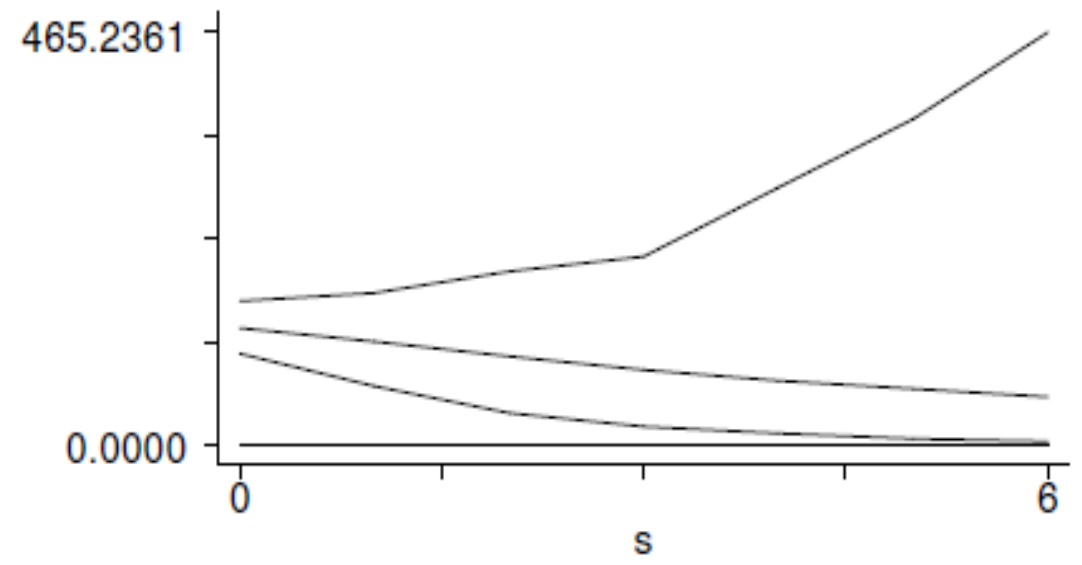


Appendix Figure 7 Impulse response of Greek CDS over swaps to debt

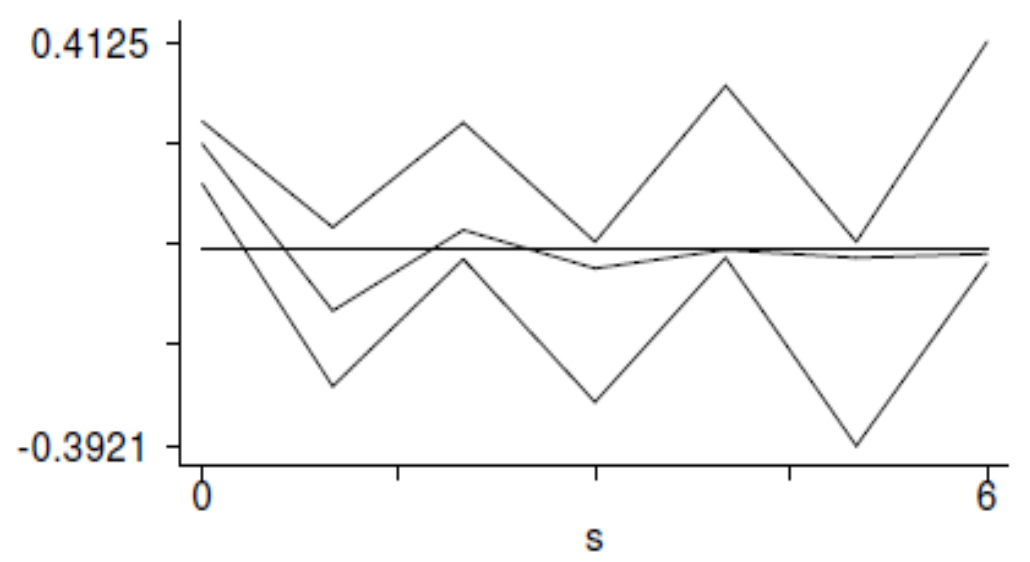

Appendix Figure 8 Impulse response of Irish CDS over swaps to debt

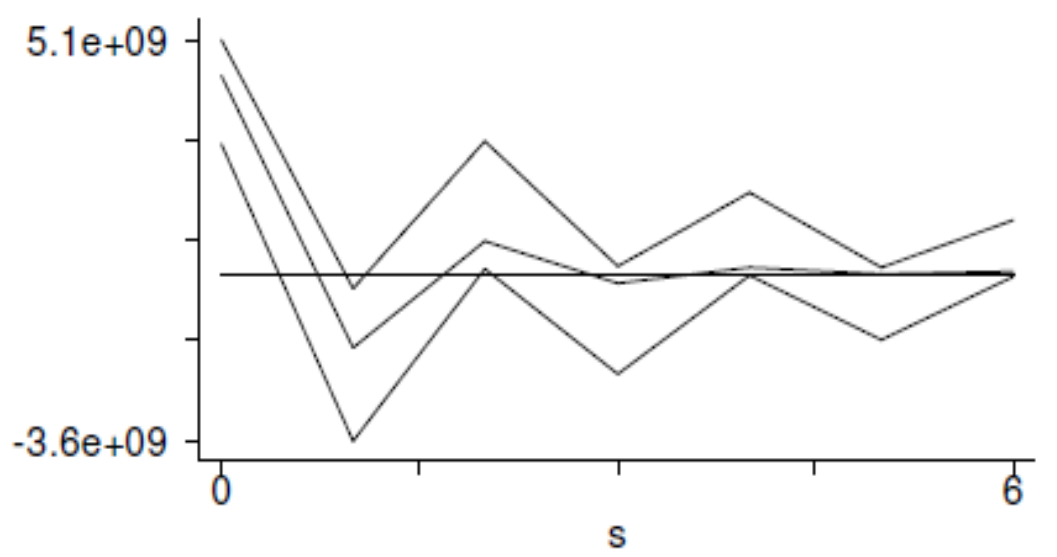

Appendix Figure 9 Impulse response of Greek CDS over swaps to the difference between Euribor and Eurepo $3 \mathrm{M}$

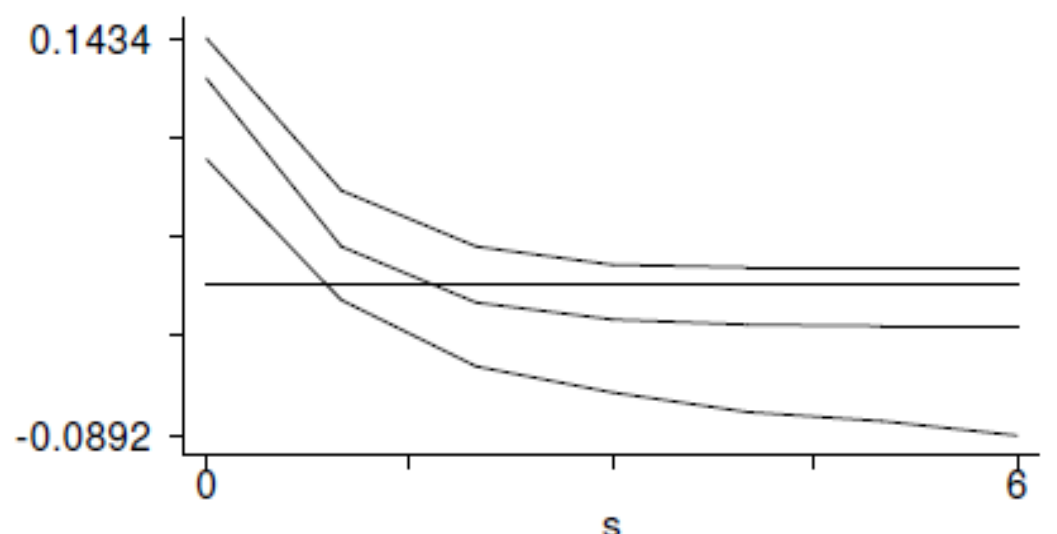


Appendix Figure 10 Impulse response of Irish CDS over swaps to the difference between Euribor and Eurepo $3 \mathrm{M}$

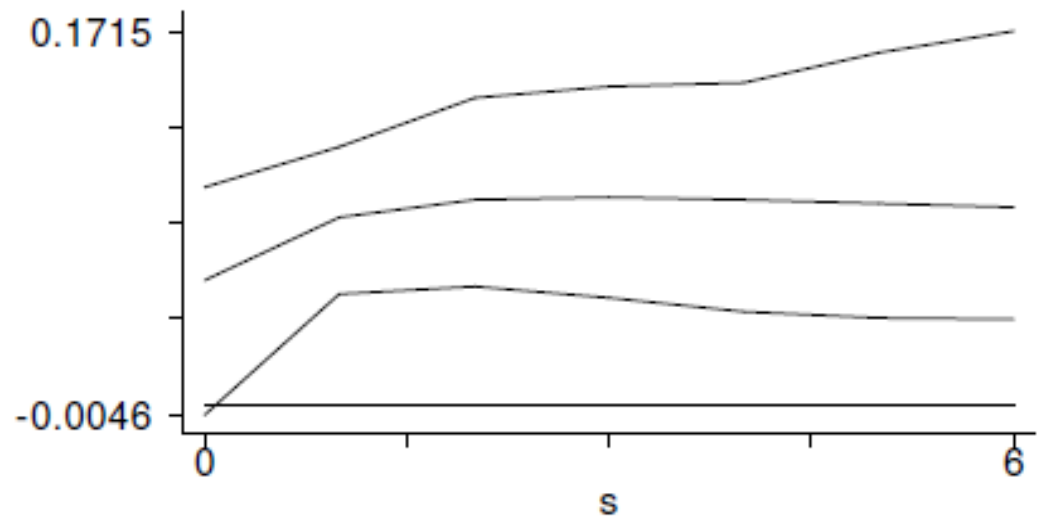

